Chirurgia (2018) 113: 353-362

No. 3, May - June

Copyright@ Celsius

http://dx.doi.org/10.21614/chirurgia.113.3.353

\title{
Therapeutical Aspects Regarding Pancreatic Pseudocysts
}

\author{
Oana Ilona David', Valentin Titus Grigorean ${ }^{1,2}$ \\ 'General Surgery Department, "Bagdasar-Arseni" Emergency Hospital, Bucharest, Romania \\ ${ }^{2} 10^{\text {th }}$ Surgical Department, "Carol Davila" University of Medicine and Farmacy, Bucharest, Romania
}

Corresponding author:

Oana llona David, MD

General Surgery Department

"Bagdasar-Arseni" Emergency Hospital

Berceni Road, 12, Bucharest

E-mail: davidoana_29@yahoo.com

\section{Rezumat}

\section{Aspecte terapeutice în pseudochistele pancreatice}

Frecvent apărute că şi complicații ale pancreatitei, pseudochistele pancreatice sunt entități rare, pentru tratamentul cărora s-au dezvoltat de-a lungul timpului multiple tehnici terapeutice, variind de la metode minim invazive la tehnici complexe de chirurgie clasică. Pseudochistele simptomatice, cele de mari dimensiuni precum şi cele ce suferă complicații evolutive de timpul hemoragiei, suprainfectiei şi rupturii au indicație de drenaj. Alegerea metodei optime de drenaj este deseori o provocare, multiplii factori trebuind să fie luați în considerare, incluzând locația pseudochistului, dimensiunea precum şi starea generală a pacientului şi comorbiditățile acestuia. Astfel, elaborarea unui algoritm terapeutic ar fi de o utilitate incontestabilă, conferind posibilitatea alegerii unei tehnici fezabile leziunii însă adaptată pacientului.

Cuvinte cheie: pancreas, pseudochist, tratament, drenaj

\section{Abstract}

Frequently appearing as a complication of pancreatitis, pancreatic pseudocysts are rare appearances in current medical practice. Multiple therapeutical options are available, from minimum invasive methods to complex open surgical techniques. The indications of drainage include symptomatic pseudocysts, large pseudocysts along with the development of complications such as hemorrhage, secondary infection, and rupture. Choosing the best drainage technique is often a challenge. Multiple factors need to be considered in managing a pseudoocyst, including its location, dimension and the patient's 
general state and comorbidities. Thus, a therapeutical algorithm may be of great use in choosing the most feasible technique for the diagnosed lesion that is also patient-adapted.

Key words: pancreas, pseudocyst, treatment, drainage

\section{Introduction}

Pancreatic pseudocysts are considerent the most frequent complication of acute and chronic pancreatitis, accounting for $75 \%$ of all pancreatic cystic lesions (1). When referring to a pancreatic pseudocyst we should consider any fluid collection located in the peripancreatic tissues (occasionally partly or wholly intrapancreatic located) (2). The location, size and age of the pseudocyst as well as the presence of complications are to be considered when implementing a therapeutical technique $(3,4)$. The lack of guidelines regarding the optimal treatment of pancreatic pseudocysts and their rather rare appearance are reasons for which continuous dilemmas are raised about their optimal management (3). Thus, comparing the therapeutical methods is mandatory in choosing the best treatment for each case.

\section{Indications of Drainage}

According to the latest data, the indications of drainage of a pancreatic pseudocyst are the presence of symptoms like pain attributable to pseudocyst, discomfort, vomit, along with the development of complications like infection, bleeding or rupture in the adjacent organs (3). Furthermore, biliary, gastric or duodenal obstruction also call for drainage, as does the increasing size of the pseudocyst at follow-up or the imagistic finding on a non-complicated pseudocyst of over $6 \mathrm{~cm}$ in diameter (3).

\section{Percutaneus Radiologic Drainage}

The main advantages of percutaneous drainage are the relatively low price and the possibility of performing it under local anesthesia. It is often done under radiologic control $(5,6)$, by using either computer tomographic (Fig. 1), ultrasonographic or fluoroscopic guidance or with endoscopic assistance (7-10). The size, location and extent, as well as the disposing of the surrounding viscera, are the main elements to be considered when choosing the approach Amongst all possible approaches, the transgastric route is most commonly chosen, having the lowest rate of complications (11-14). Other possible paths of access are transperitoneal, retroperitoneal, transduodenal, transhepatic

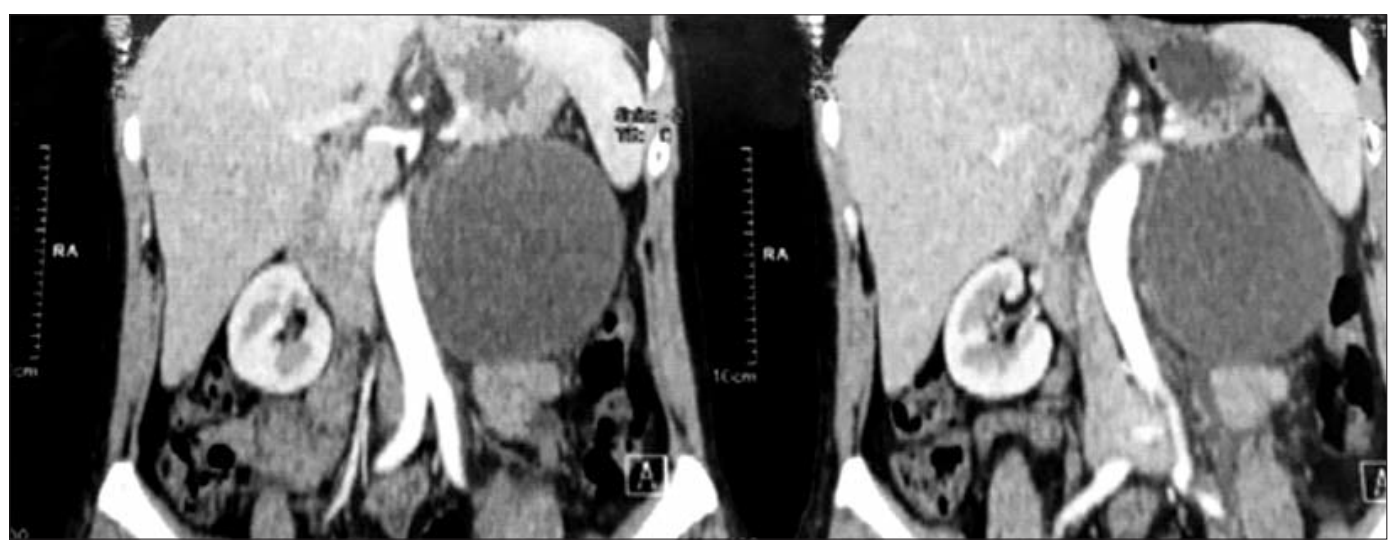

Figure 1. Pancreatic pseudocyst - CT image 
and transsplenic (15). Assessing the completion of the drainage or retained debris as well as the status of the pancreatic duct communication or potentially associated complications as is enteric fistula may be done by performing a sinography (16). The catheter may be removed when the drain output becomes minimal (less than $10 \mathrm{ml} / 24 \mathrm{~h}$ ) and there is evidence of closure of the pseudocyst-enteric fistula and/or duct communication (16). For infected pancreatic pseudocysts, the percutaneous approach is the best therapeutical option $(11-15,17,18)$. It is also useful for aiding definitive diagnosis, when in doubt, allowing amylase dosing from the aspirated fluid, cytologic analysis, and tumor marker dosing (16). It may as well be used when the location of the pseudocyst makes it inaccessible to other drainage methods more routinely used (16).

Having a low rate of mortality, the percutaneous drainage also offers the advantage of not violating the operative field in case surgery will become necessary (11). However, complications may occur, including bleeding (1-2\%) (19), lesions of the pleura or other viscera (1-2\%) (19), secondary infection (9\%) (19). Progression towards pancreatico-cutaneous fistula or recurrence in poorly selected patients having a downstream stricture of the pancreatic duct may also occur (15). These cases will require a rather prolonged period of drainage, of 3 to 6 weeks $(15,20,21)$. Yet, often a resulting pancreatico-cutaneous fistula will spontaneously resolve in $60-70 \%$ of cases (17). As far as singlestep needle drainage is concerned, it is often accompanied by a high rate of recurrence, of over $70 \%$, with a failure rate of more than $50 \%$ of cases (6). However, using a catheter for prolonged drainage results in a higher success rate, up to $100 \%$ and a low recurrence (22-23\%) (22-24).

\section{Endoscopic Drainage}

When dealing with pancreatic pseudocysts associated with chronic pancreatitic, the endoscopic approach is of election, whether using transmural or transpapilar route $(16,25)$.

\section{Transpapillary Drainage}

In $40-70 \%$ of cases, the pancreatic pseudocyst has a communication with the pancreatic duct, a fact that renders it potentially suitable for transpapillary endoscopic drainage (26-28). When the pseudocyst communicates with the main pancreatic duct or one of its side branches, as seen at ERCP, it may be drained via transpapillary insertion of a stent. The stent is meant to bridge the main pancreatic duct or a disrupted side branch (16). The procedure consists in initial biliary and pancreatic sphincterotomy followed by balloon dilatation of the pancreatic duct stricture and insertion of a stent of 5-7 Fr over the strictured area and beyond $(29,30)$. The method shows a success rate varying between 60 and $96 \%$. Its predictive factors of success include the presence of strictured areas, the pseudocysts size over $6 \mathrm{~cm}$ in diameter, location in the body of the pancreas and an evolution of the pseudocyst of less than 6 months (29). As far as the procedure's safety is concerned, there is a low morbidity and no reported mortality in patients submitted to this maneuver (29, 31-35). Among possible complications, hemorrhage is reported in less than $1 \%$ of cases, postprocedural pancreatitis in $5 \%$ of cases while stent migration is considered extremely rare $(29,31-35)$. Some authors reported stent obstruction in secondary infections of the pseudocyst, in which case stent change alone may be the only necessary maneuver $(29,34,35)$. The presence of stents in the pancreatic duct is not without consequence, its sole presence leading to strictures similar to those seen in patients suffering from chronic pancreatitis $(36,37)$. However, these strictures are frequently without functional consequences, being often spontaneously reversible (38).

\section{Transmural Drainage}

Depending on the pseudocysts location, the access for transmural endoscopic drainage may be obtained through transgastric or transduodenal approach (16). During the procedure, endoscopic identification of the area of the maximum bulge is performed, using a sideviewing endoscope. Entering the pseudocyst is 
done using a needle-knife papillotome with subsequent radiological verification by contrast injection; only then a 7-10 Fr stent may be inserted (35, 39). Concomitant echoendoscopy may be useful for excluding neoplastic lesions or for showing thick-walled pseudocysts or those with marked necrosis (accounting for approximately $50 \%$ of patients); it il also able to establish that an endoscopic approach is indeed indicated for the respective lesion (40). Furthermore, echoendoscopy may establish the best point of entry into the pseudocyst, especially when dealing with imprecise intraluminal contour (41). It helps guide the drainage (42-47) thus decreasing the hemorrhage risk by easily avoiding blood vessels and pseudoanevrisms $(48,49)$. In order to rule out malignant lesions or pancreatic cystadenoma, a biopsy of the wall of the pseudocyst may be performed (50). The stent is maintained for 2-4 months or until radiological proof of pseudocyst resolution and the catheter may be changed if necessary by endoscopic approach (16). The reported cases in the literature reach a success rate between $36^{-}$ $90 \%$, varying with respecting the selection criteria for this particular method (25, 33-36, 40, $44,49,51-54)$. A high rate of success is seen in patients having pseudocysts located in the head and body of the pancreas, pseudocysts with a transmural thickness less than $1 \mathrm{~cm}$ as seen on computer tomography or echoendoscopy or complicating chronic pancreatitis rather than an acute necrotizing pancreatitis $(25,32,35,53-$ 55). Intra- and postprocedural complications (occurring in under 7\% of cases) include bleeding, perforation and sepsis (30), the latest being secondary to infection of necrosis within the pancreatic pseudocyst. In order to minimize the risk of secondary infection, it is important to create a large communication between the cavity of the pseudocyst and the gastric or duodenal lumen, thus favoring an efficient drainage of the content of the pseudocyst $(29,56)$. Another suggested method for reducing infection rate is performing cyst lavage on an endoscopically placed nasocystic catheter $(29,56)$. Studies suggest that despite a relatively high rate of complications and reccurence the endoscopic drainage of pancreatic pseudocysts has a signifi- cantly diminished mortality rate, as compared with open surgical procedures (30)

\section{Laparoscopic Surgery}

Traditional methods of drainage of pancreatic pseudocysts were accompanied by a high rate of morbidity and mortality $(57,58)$. The laparoscopic techniques, once developed, allowed the drainage of pancreatic pseudocysts using the same principles as open surgery, but with a minimally invasive approach. The purpose is to create a large pseudocyst enterostomy and to perform the debridement of the pseudocyst contents. Three types of approaches may be used for internally draining large retrogastric pseudocysts, namely endogastric (57, 59-65), transgastric $(57,64,66,67)$ or extragastric $(57$, $58,68)$ approach. The transgastric approach involves establishing the access to the posterior gastric wall through an anterior gastrectomy. When choosing an endogastric approach, the access is achieved by introducing three ports, including the laparoscope into the gastric lumen. When performing an extragastric approach, we aim to visualize the posterior wall - pseudocyst interface by creating a division in the gastrocolic omentum (16). Ascertaining the location of the pseudocyst is done by inserting an aspiration needle or of a flexible-tip endoscopic ultrasound (63). Often, after creating a large fenestration, a biopsy of the pseudocyst wall is performed, followed by the debridement and lavaje of the content, that may be necrotic (16). When dealing with a pseudocyst located in the pancreatic tail, the drainage requires performing a Roux-en-Y pseudocyst-jejunal anastomosis $(60,69,70)$ or a loop pseudocyst jejunostomy.

The laparoscopic pseudocyst gastrostomy offers the advantage of a short postoperative stay and of a high success rate, of up to $89 \%$ (57, $59,62,64)$. No recurrences were reported for this procedure at follow-up (57, 59, 62, 64). Conversion to open surgery may be required in case of bleeding or other technical difficulties, with a conversion rate of under $7 \%,(64)$. Conversion is rarely encountered in wellestablished pseudocysts (59). The reported 
complications include infection of the pseudocysts content as well as reccurence of the pseudocyst, in case of performing an inadequate anastomosis $(57,64)$. Laparoscopic drainage of acute pseudocysts allow concomitant pancreatic necrosectomy, and, as compared to endoscopic and percutaneous methods (64) it offers the advantage of creating a relatively large pseudocyst enterostomy, thus facilitating more efficient drainage. Furthermore, creating a large cyst-gastric connection decreases the risk of obstruction of the anastomosis as well as the risk of infection and bleeding (16). Despite good short-term results (Table 1), the long-term reccurance rate is expected to be similar to open surgery $(5-20 \%)(57,64,66,71-73)$.

\section{Open Surgical Tehniques}

Internal drainage of pancreatic pseudocysts, using classical surgical tehnicques, was historically considered of election for mature, uncomplicated pseudocysts (3). The technical options for internal drainage of a pancreatic pseudocyst include cystogastrostomy, cystoduodenostomy and cystojejunostomy using a Roux-en-Y pseudocyst-jejunal anastomosis. The type of the operation is chosen according to the pseudocysts location and to the nearest by organ pertaining to the gastrointestinal tract $(3,74)$. For pancreatic pseudocysts densely adherent to the posterior wall of the stomach, cystogastrostomy is of choice (75). On the other side, pseudocysts located in the head and uncinate process of the pancreas are drained by cystiduodenostomy (75). For all remaining pseudocysts, especially for large ones ( $>15 \mathrm{~cm}$ in diameter), a cystojejunostomy is considered the appropriate technique (75).
When considering all surgical treatment methods for pancreatic pseudocysts, authors evaluate the morbidity rate somewhere between $10-30 \%$ whilst the mortality rate varies between $1-5 \%$. The five years recurrence reaches $20 \%$ in some studies $(38,74)$.

The indications of excision of pseudocysts located in the body or tail of the pancreas through distal pancreatectomy, with or without splenectomy are limited. It is reserved for the treatment of complications such as bleeding from a pseudoaneurysm or for true cysts or cystic neoplasies discovered by biopsy of the cystic wall during surgery $(76,77)$. Due to the fact that resection is technically more difficult, with higher morbi-mortality and may possibly result in loss of pancreatic function, internal drainage is usually preferred for surgically treating pancreatic pseudocysts (75). Pancreatic resection for pseudocysts is accompanied by a complication rate of $34 \%$ and a mortality rate of 8.5\% (78). Amongst early complications, pneumonia, intraabdominal infections, hemorrhage and postoperative pancreatitis are the most frequent (76). In the late postoperative period, patients may develop diabetes, chronic pancreatic fistulas or chronic pancreatic insufficiency (76). External surgical drainage, although frequently performed in the past, nowadays has few indications $(3,76)$. In cases in which anastomotic dehiscence is very likely to occur (because of either unexpectedly infected pseudocyst or unanticipated immature wall, incapable of holding sutures or in case of misdiagnosis) external drainage may still be used $(3,76)$. The main disadvantage of external drainage is the potential for bleeding due to mechanical abrasion produced by the drainage tube $(3,75$, 76). Moreover, the risk of secondary infection is

Table 1. Laparoscopic pseudocyst-gastrostomy

\begin{tabular}{lccccc}
\hline Reference & Tehnique & Complications & Success rate & Conversion & Reccurance \\
\hline Smadja et al.(67) & Transgastic & $0 \%$ & $100 \%$ & 0 & N/A \\
\hline Ammori et al.(59) & Endogastric & $0 \%$ & $100 \%$ & 0 & 0 \\
\hline Chowbey et al.(62) & Endogastric & N/A & $100 \%$ & 0 & N/A \\
\hline Park et al.(57) & Exogastric & $17 \%$ & $100 \%$ & 0 & 0 \\
\hline Mori et al.(64) & Endogastric & $8 \%$ & $77 \%$ & $15 \%$ & 0 \\
\hline
\end{tabular}


high as is the risk of persistent pancreatic fistula (in 10\% of patients) requiring subsequent distal pancreatectomy or Roux-en-Y pseudocystjejunal anastomosis for drainage (76). External pancreatic drainage, done by classic surgical techniques has a recurrence rate of $18 \%$ and a mortality rate of $10 \%(3,75,76)$. Responsible for the high mortality rate is often the patient's extremely poor condition when submitted to the surgical procedure (76). The cyst wall biopsy is mandatory, regardless of the procedure of surgical drainage elected. Finding any type of endothelium in the wall at histological examination indicates that the lesion is, in fact, a true cyst or a cystic neoplasia, rather than a pancreatic pseudocyst (76). Corroborating all surgical techniques for treating pancreatic pseudocysts, pertaining to classic open surgery we discover a mortality rate of under $1 \%$ but with a morbidity of nearly $30 \%$ and a recurrence rate of $6 \%$ $(22,79)$.

Thus, the indications for classic open surgical management of pancreatic pseudocysts are limited $(76,80)$. It is indicated for treating complicated pancreatic pseudocysts that form in the setting of acute pancreatitis, accompanied by extensive pancreatic modifications, inflammation, abscesses and pancreatic necrosis, in which case endoscopic drainage is ineffective $(76,80)$. Sole pseudocyst drainage is futile, concomitant necrosectomy and debridement being necessary. Another indication is pancreatic pseudocysts associating a pancreatic duct stricture impossible to treat by transpapillary approach (due to the possibility of determining a pancreatic duct dilatation and forming of another pseudocyst behind the stricture). Surgery is performed in order to decompress the duct beyond the stricture, correcting both the pseudocyst and its cause. Only draining the pseudocyst may result in pseudocyst recurrence or in the onset of another episode of pancreatitis $(76,80)$. For cases in which the etiological diagnosis cannot be certainly established, open surgery is also of choice, sometimes the pancreatic lesion not being able to be differentiated from a neoplastic cyst or benign essential cyst (76). Morover, for cases of pancreatic pseudocysts connected to the biliary tract, also associating a bile duct stricture of over $2 \mathrm{~cm}$ in length (cases for which endoscopic sphincterotomy cannot be successfully applied) open surgery is of great use (76). Another situation is in cases of intracystic hemorrhage caused by erosion of the pancreatic pseudocyst into the splenic or gastroduodenal artery, with a failed attempt of angiographic hemostasis $(76,80)$. Moreover, open surgery is usefull for cases in which uncontrolled hemorrhage occurs or when minimal invasive treatment fails (76).

\section{Comparative Study of Theraputical Options}

Studies regarding the treatment of pancreatic pseudocysts mention a great variety of results regarding multiple therapeutical alternatives.

Heider et al. prove that patients treated by percutaneous approach have a higher mortality rate as compared to patients treated with open surgery, also having an increased duration of hospitalization (5). Moreover, Morton et al. show that patients treated with surgical drainage have fewer complications, less mortality and diminished hospital stay (81) (Table 2).

Akshintala et al. show that percutaneous drainage has higher rates of reintervention despite a similar success rate to endoscopic drainage but patients need a longer hospital stay (82). Two years later, Keane et al. show that endoscopic drainage has higher rates of treatment success, lower rates of reintervention, the patients requiring shorter hospitalization (83) (Table 3).

As far as the advantages of transmural echoendoscopic guided drainage are concerned multiple studies showed a higher success rate as compared to classic radiological guided transmural drainage but with similar results and long-term complications $(84,85)$ (Table 4).

Despite similar rates of success, reintervention and complications, echoendoscopic guided transmural drainage is more advantageous as compared to surgical drainage due to requiring less hospital stay and fewer costs $(86,87)$ (Table 5).

Melman et al. show that surgical drainage has a better primary success rate compared to endoscopic drainage, but both have similar 
Table 2. Percutaneous drainage vs. surgical drainage

\begin{tabular}{|c|c|c|c|c|c|c|c|}
\hline \multicolumn{2}{|l|}{ Study } & \multicolumn{3}{|c|}{ Percutaneous drainage } & \multicolumn{3}{|c|}{ Surgical drainage } \\
\hline $\begin{array}{l}\text { Name } \\
\text { stay }\end{array}$ & Type & Morbidity & Mortality & Hospital stay & Morbidity & Mortality & Hospital \\
\hline Heider et al. (5) & Retrospective & +++ & +++ & +++ & + & + & + \\
\hline Morton et al. (81) & Retrospective & + & + & + & ++ & ++ & ++ \\
\hline
\end{tabular}

Table 3. Percutaneous drainage vs. endoscopic drainage

\begin{tabular}{|c|c|c|c|c|c|c|c|}
\hline \multicolumn{2}{|l|}{ Study } & \multicolumn{3}{|c|}{ Percutaneous drainage } & \multicolumn{3}{|c|}{ Endoscopic drainage } \\
\hline Name & Type & $\begin{array}{l}\text { Reintervention } \\
\text { rate }\end{array}$ & $\begin{array}{l}\text { Success } \\
\text { rate }\end{array}$ & $\begin{array}{c}\text { Hospital } \\
\text { stay }\end{array}$ & $\begin{array}{l}\text { Reintervention } \\
\text { rate }\end{array}$ & $\begin{array}{l}\text { Success } \\
\text { rate }\end{array}$ & $\begin{array}{l}\text { Hospital } \\
\text { stay }\end{array}$ \\
\hline Akshintala et al.. (82) & Retrospective & ++ & ++ & ++ & + & ++ & + \\
\hline Keane et al.(83) & Retrospective & ++ & + & ++ & + & ++ & + \\
\hline
\end{tabular}

Table 4. Classic transmural drainage vs. ecoendoscopic guided transmural drainage

\begin{tabular}{llcccccc}
\hline & Study & & \multicolumn{2}{c}{ Classic transmural drainage } & \multicolumn{3}{c}{$\begin{array}{c}\text { Ecoendoscopic guided transmural } \\
\text { drainage }\end{array}$} \\
\hline Name & Type & Success & Complication & Reccurance \\
& & & rate & rate & Success & Complication & Reccurance \\
rate & rate & rate & rate \\
Varadarajulu et al.(85) & Randomized & + & + & + & ++ & + & + \\
\hdashline Park et al.(84) & Randomized & + & + & + & ++ & + & + \\
\hline
\end{tabular}

Table 5. Surgical drainage vs. ecoendoscopic guided transmural drainage

\begin{tabular}{|c|c|c|c|c|c|c|c|}
\hline \multicolumn{2}{|l|}{ Study } & \multicolumn{3}{|c|}{ Surgical drainage } & \multicolumn{3}{|c|}{$\begin{array}{l}\text { Ecoendoscopic guided transmural } \\
\text { drainage }\end{array}$} \\
\hline Name & Type & $\begin{array}{l}\text { Success } \\
\text { rate }\end{array}$ & $\begin{array}{c}\text { Complication } \\
\text { and reintervention } \\
\text { rate }\end{array}$ & $\begin{array}{l}\text { Hospital } \\
\text { stay }\end{array}$ & $\begin{array}{l}\text { Success } \\
\text { rate }\end{array}$ & $\begin{array}{c}\text { Complication } \\
\text { and reintervention } \\
\text { rate }\end{array}$ & $\begin{array}{l}\text { Hospital } \\
\text { stay }\end{array}$ \\
\hline Varadarajulu et al.(87) & Retrospective & + & + & ++ & + & + & + \\
\hline Varadarajulu et al.(86) & Randomized & + & + & ++ & + & + & + \\
\hline
\end{tabular}

Table 6. Endoscopic drainage vs. surgical drainage

\begin{tabular}{llcccc}
\hline & Study & \multicolumn{2}{c}{ Endoscopic drainage } & \multicolumn{2}{c}{ Surgical drainage (laparoscopic/open) } \\
\hline Name & Type & $\begin{array}{c}\text { Success } \\
\text { rate }\end{array}$ & $\begin{array}{c}\text { Complication } \\
\text { rate }\end{array}$ & $\begin{array}{c}\text { Success } \\
\text { rate }\end{array}$ & $\begin{array}{c}\text { Complication } \\
\text { rate }\end{array}$ \\
\hline Melman et al. (88) & Retrospective & + & + & ++ & + \\
\hline
\end{tabular}

rates of complications (88) (Table 6).

Studies show a great variety of diagnostic and therapeutical techniques. These methods are intensely put under debate as far as indications and advantages are concerned. Often, certain surgical centers show a specific preference in choosing a certain method and their experience usually materializes in exceptional success rates. So, different opinions in supporting a therapeutical approach, often based on extensive studies, are not uncommon. The curve of learning is nevertheless an important predictive factor for the subsequent results. While taking into account the success and complications rates mentioned by various authors, we find it useful to apply a therapeutical algorithm when drainage is indicated for pancreatic pseudocysts. Thus, we find that 
endoscopic drainage, with the two subtypes of approach - transpapilary and transmural should be first considered when needing to drain a pancreatic pseudocyst. Furthermore, the advantages of conventional radiologic methods are incontestable, situating them nevertheless right after the endoscopic techniques in the hierarchy of therapeutical measures. We propose a third method to be considered laparoscopic surgery, followed by open surgical techniques. We see the percutaneous drainage as the last option to be considered due to the potential risks and complications, being nevertheless the only feasible technique for selected cases.

\section{Conclusions}

The constant interest in developing new treatment methods for pancreatic pseudocysts and standardizing the treatment indications led, over the years, to a transition from invasive methods to more patient-adapted methods. These therapeutical options are associated with minimum risk of complications and maximum rates of success. Although percutaneous and endoscopic methods possess the advantages of safety, increased efficacity and possibility to be applied to patients with a poor general state, the historical gold standard represented by surgical drainage techniques is still irreplaceable for large pseudocysts or pseudocysts that showed evolutive complications. An overall view of the indications and complications may lead to the development of a therapeutical algorithm of incontestable utility in choosing the most efficient technique for each patient with minimum periprocedural risk.

Conflict of Interest: none declared.

\section{References}

1. Beuran M, Negoi I, Catena F, Sartelli M, Hostiuc S, Paun S. Laparoscopic Transgastric versus Endoscopic Drainage of a Large Pancreatic Pseudocyst. A Case Report. Journal of gastrointestinal and liver diseases : JGLD. 2016;25(2):243-7.

2. Banks PA, Bollen TL, Dervenis C, Gooszen HG, Johnson CD, Sarr $M G$, et al. Classification of acute pancreatitis-2012: revision of the Atlanta classification and definitions by international consensus. Gut. 2013;62(1):102-11.
3. Agalianos C, Passas I, Sideris I, Davides D, Dervenis C. Review of management options for pancreatic pseudocysts. Translational gastroenterology and hepatology. 2018;3:18.

4. Popescu, Tomescu D. Tratat de chirurgie hepato-bilio-pancreatică si transplant hepatic / textbook of hepatobiliary and pancreatic surgery and liver transplantation2016.

5. Heider R, Meyer AA, Galanko JA, Behrns KE. Percutaneous drainage of pancreatic pseudocysts is associated with a higher failure rate than surgical treatment in unselected patients. Annals of surgery. 1999;229(6):781-7; discussion 7-9.

6. Gumaste UV, Dave PB. Pancreatic pseudocyst drainage--the needle or the scalpel? Journal of clinical gastroenterology. 1991;13(5): 500-5.

7. Obrador A, Pueyo J, Gaya J, Llompart A. Combined percutaneousendoscopic pancreatic pseudocyst drainage--a new technique. Endoscopy. 1998;30(5):499-503.

8. White $S A$, Sutton CD, Berry DP, Chillistone D, Rees Y, Dennison AR. Experience of combined endoscopic percutaneous stenting with ultrasound guidance for drainage of pancreatic pseudocycts. Annals of the Royal College of Surgeons of England. 2000; 82(1):11-5.

9. Atabek U, Mayer D, Amin A, Camishion RC. Pancreatic cystogastrostomy by combined upper endoscopy and percutaneous transgastric instrumentation. Journal of laparoendoscopic surgery. 1993;3(5):501-4.

10. Sever M, Vidmar D, Surlan M, Pleskovic A, Visnar-Perovic A. Percutaneous drainage of pancreatic pseudocyst into the stomach. Surgical endoscopy. 1998;12(10):1249-53.

11. Sacks D, Robinson ML. Transgastric percutaneous drainage of pancreatic pseudocysts. AJR Am J Roentgenol. 1988;151(2):303-6.

12. Matzinger FR, Ho CS, Yee AC, Gray RR. Pancreatic pseudocysts drained through a percutaneous transgastric approach: further experience. Radiology. 1988;167(2):431-4.

13. Kuligowska E, Olsen WL. Pancreatic pseudocysts drained through a percutaneous transgastric approach. Radiology. 1985;154(1):79-82.

14. Ho CS, Taylor B. Percutaneous transgastric drainage for pancreatic pseudocyst. AJR Am J Roentgenol. 1984;143(3):623-5.

15. vanSonnenberg E, Wittich GR, Casola G, Brannigan TC, Karnel F, Stabile BE, et al. Percutaneous drainage of infected and noninfected pancreatic pseudocysts: experience in 101 cases. Radiology. 1989; 170(3 Pt 1):757-61.

16. Bhattacharya D, Ammori BJ. Minimally invasive approaches to the management of pancreatic pseudocysts: review of the literature. Surgical laparoscopy, endoscopy \& percutaneous techniques. 2003;13(3):141-8.

17. Tsiotos GG, Sarr MG. Management of fluid collections and necrosis in acute pancreatitis. Current gastroenterology reports. 1999;1(2):139-44.

18. Polakow J, Ladny JR, Serwatka W, Walecki J, Puchalski Z, Czech B. Percutaneous fine-needle pancreatic pseudocyst puncture guided by three-dimensional sonography. Hepato-gastroenterology. 2001; 48(41):1308-11.

19. Neff R. Pancreatic pseudocysts and fluid collections: percutaneous approaches. The Surgical clinics of North America. 2001;81(2): 399-403, xii.

20. Adams DB, Anderson MC. Percutaneous catheter drainage compared with internal drainage in the management of pancreatic pseudocyst. Annals of surgery. 1992;215(6):571-6; discussion 6-8.

21. Puri SK, Kumar N, Panicker H, Gupta S, Sachdev AK, Chaudhary A, et al. Percutaneous catheter drainage in pancreatic pseudocysts. Tropical gastroenterology : official journal of the Digestive Diseases Foundation. 1996;17(3):181-4.

22. Spivak H, Galloway JR, Amerson JR, Fink AS, Branum GD, Redvanly RD, et al. Management of pancreatic pseudocysts. Journal of the American College of Surgeons. 1998;186(5):507-11.

23. Freeny PC. Percutaneous management of pancreatic fluid collections. Bailliere's clinical gastroenterology. 1992;6(2):259-72.

24. Grosso M, Gandini G, Cassinis MC, Regge D, Righi D, Rossi P. Percutaneous treatment (including pseudocystogastrostomy) of 74 pancreatic pseudocysts. Radiology. 1989;173(2):493-7. 
25. Libera ED, Siqueira ES, Morais M, Rohr MR, Brant CQ, Ardengh JC, et al. Pancreatic pseudocysts transpapillary and transmural drainage. HPB surgery : a world journal of hepatic, pancreatic and biliary surgery. 2000;11(5):333-8.

26. Kolars JC, Allen MO, Ansel H, Silvis SE, Vennes JA. Pancreatic pseudocysts: clinical and endoscopic experience. The American journal of gastroenterology. 1989;84(3):259-64.

27. Liguory C, Lefebvre JF, Vitale G, Bonnel D, Cornud F. [Endoscopic and transhepatic intubation of malignant bile duct strictures for postoperative jaundice]. Annales de chirurgie. 1991;45(6):471-5.

28. Barkin JS, Hyder SA. Changing concepts in the management of pancreatic pseudocysts. Gastrointestinal endoscopy. 1989; 35(1):62-4.

29. Catalano MF, Geenen JE, Schmalz MJ, Johnson GK, Dean RS, Hogan WJ. Treatment of pancreatic pseudocysts with ductal communication by transpapillary pancreatic duct endoprosthesis. Gastrointestinal endoscopy. 1995;42(3):214-8.

30. Vidyarthi G, Steinberg SE. Endoscopic management of pancreatic pseudocysts. The Surgical clinics of North America. 2001; 81(2): 405-10, xii.

31. Kozarek RA, Brayko CM, Harlan J, Sanowski RA, Cintora I, Kovac A. Endoscopic drainage of pancreatic pseudocysts. Gastrointestinal endoscopy. 1985;31(5):322-7.

32. Dohmoto M, Rupp KD. Endoscopic management of pancreatic pseudocysts. Diagnostic and therapeutic endoscopy. 1994;1(1):29-35.

33. Binmoeller KF, Seifert H, Walter A, Soehendra N. Transpapillary and transmural drainage of pancreatic pseudocysts. Gastrointestinal endoscopy. 1995;42(3):219-24.

34. Barthet M, Sahel J, Bodiou-Bertei C, Bernard JP. Endoscopic transpapillary drainage of pancreatic pseudocysts. Gastrointestinal endoscopy. 1995;42(3):208-13.

35. Smits ME, Rauws EA, Tytgat GN, Huibregtse K. The efficacy of endoscopic treatment of pancreatic pseudocysts. Gastrointestinal endoscopy. 1995;42(3):202-7.

36. Kozarek RA. Pancreatic stents can induce ductal changes consistent with chronic pancreatitis. Gastrointestinal endoscopy. 1990; 36(2):93-5.

37. Sherman S, Alvarez C, Robert M, Ashley SW, Reber HA, Lehman GA. Polyethylene pancreatic duct stent-induced changes in the normal dog pancreas. Gastrointestinal endoscopy. 1993;39(5):658-64.

38. Huibregtse K, Schneider B, Vrij AA, Tytgat GN. Endoscopic pancreatic drainage in chronic pancreatitis. Gastrointestinal endoscopy. 1988;34(1):9-15

39. Funnell IC, Bornman PC, Krige JE, Beningfield SJ, Terblanche J. Complete common bile duct division at laparoscopic cholecystectomy: management by percutaneous drainage and endoscopic stenting. The British journal of surgery. 1993;80(8):1053-4.

40. Beckingham IJ, Krige JE, Bornman PC, Terblanche J. Long term outcome of endoscopic drainage of pancreatic pseudocysts. The American journal of gastroenterology. 1999;94(1):71-4.

41. Chan AT, Heller SJ, Van Dam J, Carr-Locke DL, Banks PA. Endoscopic cystgastrostomy: role of endoscopic ultrasonography. The American journal of gastroenterology. 1996;91(8):1622-5.

42. Baron TH, Wiersema MJ. EUS-guided transesophageal pancreatic pseudocyst drainage. Gastrointestinal endoscopy. 2000;52(4):545-9.

43. Fuchs M, Reimann FM, Gaebel C, Ludwig D, Stange EF. Treatment of infected pancreatic pseudocysts by endoscopic ultrasonographyguided cystogastrostomy. Endoscopy. 2000;32(8):654-7.

44. Giovannini M, Pesenti C, Rolland AL, Moutardier V, Delpero JR. Endoscopic ultrasound-guided drainage of pancreatic pseudocysts or pancreatic abscesses using a therapeutic echo endoscope. Endoscopy. 2001;33(6):473-7.

45. Inui K, Yoshino J, Okushima K, Miyoshi H, Nakamura Y, Watanabe $\mathrm{S}$, et al. EUS-guided one-step drainage of pancreatic pseudocysts: experience in 3 patients. Gastrointestinal endoscopy. 2001; $54(1): 87-9$

46. Seifert $H$, Dietrich $C$, Schmitt $T$, Caspary W, Wehrmann T.
Endoscopic ultrasound-guided one-step transmural drainage of cystic abdominal lesions with a large-channel echo endoscope. Endoscopy. 2000;32(3):255-9.

47. Vilmann P, Hancke S, Pless T, Schell-Hincke JD, Henriksen FW. One-step endosonography-guided drainage of a pancreatic pseudocyst: a new technique of stent delivery through the echo endoscope. Endoscopy. 1998;30(8):730-3.

48. Wiersema MJ. Endosonography-guided cystoduodenostomy with a therapeutic ultrasound endoscope. Gastrointestinal endoscopy. 1996;44(5):614-7.

49. Norton ID, Clain JE, Wiersema MJ, DiMagno EP, Petersen BT, Gostout CJ. Utility of endoscopic ultrasonography in endoscopic drainage of pancreatic pseudocysts in selected patients. Mayo Clinic proceedings. 2001;76(8):794-8.

50. Fockens P, Johnson TG, van Dullemen HM, Huibregtse K, Tytgat GN. Endosonographic imaging of pancreatic pseudocysts before endoscopic transmural drainage. Gastrointestinal endoscopy. 1997;46(5):412-6.

51. Vitale GC, Lawhon JC, Larson GM, Harrell DJ, Reed DN, Jr., MacLeod S. Endoscopic drainage of the pancreatic pseudocyst. Surgery. 1999:126(4):616-21; discussion 21-3.

52. Deviere J, Bueso H, Baize M, Azar C, Love J, Moreno E, et al. Complete disruption of the main pancreatic duct: endoscopic management. Gastrointestinal endoscopy. 1995;42(5):445-51.

53. Sahel J, Bastid C, Pellat B, Schurgers P, Sarles H. Endoscopic cystoduodenostomy of cysts of chronic calcifying pancreatitis: a report of 20 cases. Pancreas. 1987;2(4):447-53.

54. Cremer M, Deviere J, Engelholm L. Endoscopic management of cysts and pseudocysts in chronic pancreatitis: long-term follow-up after 7 years of experience. Gastrointestinal endoscopy. 1989; 35(1):1-9.

55. Grimm H, Binmoeller KF, Soehendra N. Endosonography-guided drainage of a pancreatic pseudocyst. Gastrointestinal endoscopy. 1992;38(2):170-1.

56. Chak A. Endosonographic-guided therapy of pancreatic pseudocysts. Gastrointestinal endoscopy. 2000;52(6 Suppl):S23-7.

57. Park A, Schwartz R, Tandan V, Anvari M. Laparoscopic pancreatic surgery. American journal of surgery. 1999;177(2):158-63.

58. Farrell TM, Hunter JG. Endogastric surgery. Seminars in laparoscopic surgery. 2000;7(1):22-5.

59. Ammori BJ, Bhattacharya D, Senapati PS. Laparoscopic endogastric pseudocyst gastrostomy: a report of three cases. Surgical laparoscopy, endoscopy \& percutaneous techniques. 2002;12(6): 437-40.

60. Hagopian EJ, Teixeira JA, Smith M, Steichen FM. Pancreatic pseudocyst treated by laparoscopic Roux-en-Y cystojejunostomy. Report of a case and review of the literature. Surgical endoscopy. 2000;14(10):967.

61. Holeczy P, Danis J. Laparoscopic transgastric pancreatic pseudocystogastrostomy--first experience with extraluminal approach. Hepato-gastroenterology. 1998;45(24):2215-8.

62. Chowbey PK, Soni V, Sharma A, Khullar R, Baijal M, Vashistha A. Laparoscopic intragastric stapled cystogastrostomy for pancreatic pseudocyst. Journal of laparoendoscopic \& advanced surgical techniques Part A. 2001;11(4):201-5.

63. Trias M, Targarona EM, Balague C, Cifuentes A, Taura P. Intraluminal stapled laparoscopic cystogastrostomy for treatment of pancreatic pseudocyst. The British journal of surgery. 1995; 82(3):403.

64. Mori T, Abe N, Sugiyama M, Atomi Y, Way LW. Laparoscopic pancreatic cystgastrostomy. Journal of hepato-biliary-pancreatic surgery. 2000;7(1):28-34.

65. Corvera CU, Kirkwood KS. Recent advances. General surgery. BMJ (Clinical research ed). 1997;315(7108):586-9.

66. Shekhar C, Maher B, Forde C, Mahon BS. Endoscopic ultrasoundguided pancreatic fluid collections' transmural drainage outcomes in 100 consecutive cases of pseudocysts and walled off necrosis: a 
single-centre experience from the United Kingdom. Scandinavian journal of gastroenterology. 2017:1-5.

67. Smadja C, Badawy A, Vons C, Giraud V, Franco D. Laparoscopic cystogastrostomy for pancreatic pseudocyst is safe and effective. Journal of laparoendoscopic \& advanced surgical techniques Part A. 1999;9(5):401-3.

68. Fernandez-Cruz L, Saenz A, Astudillo E, Pantoja JP, Uzcategui E, Navarro S. Laparoscopic pancreatic surgery in patients with chronic pancreatitis. Surgical endoscopy. 2002;16(6):996-1003.

69. Teixeira J, Gibbs KE, Vaimakis S, Rezayat C. Laparoscopic Rouxen-Y pancreatic cyst-jejunostomy. Surgical endoscopy. 2003; 17(12):1910-3

70. Frantzides CT, Ludwig KA, Redlich PN. Laparoscopic management of a pancreatic pseudocyst. Journal of laparoendoscopic surgery. 1994;4(1):55-9.

71. Williams KJ, Fabian TC. Pancreatic pseudocyst: recommendations for operative and nonoperative management. The American surgeon. 1992;58(3):199-205.

72. Moran B, Rew DA, Johnson CD. Pancreatic pseudocyst should be treated by surgical drainage. Annals of the Royal College of Surgeons of England. 1994;76(1):54-8.

73. Roth JS, Park AE. Laparoscopic pancreatic cystgastrostomy: the lesser sac technique. Surgical laparoscopy, endoscopy \& percutaneous techniques. 2001;11(3):201-3.

74. Kohler H, Schafmayer A, Ludtke FE, Lepsien G, Peiper HJ. Surgical treatment of pancreatic pseudocysts. The British journal of surgery. 1987;74(9):813-5

75. Pitchumoni CS, Agarwal N. Pancreatic pseudocysts. When and how should drainage be performed? Gastroenterology clinics of North America. 1999;28(3):615-39.

76. Vosoghi M, Sial S, Garrett B, Feng J, Lee T, Stabile BE, et al. EUSguided pancreatic pseudocyst drainage: review and experience a Harbor-UCLA Medical Center. MedGenMed: Medscape general medicine. 2002;4(3):2.

77. Andronescu P, Miron A. The surgical treatment of pancreatic cysts and pseudocysts. Chirurgia (Bucur). 1995; 44(2):1-8

78. Gumaste VV, Pitchumoni CS. Pancreatic pseudocyst. The Gastroenterologist. 1996;4(1):33-43.
79. Usatoff V, Brancatisano R, Williamson RC. Operative treatment of pseudocysts in patients with chronic pancreatitis. The British journal of surgery. 2000;87(11):1494-9.

80. Cooperman AM. Surgical treatment of pancreatic pseudocysts. The Surgical clinics of North America. 2001;81(2):411-9, xii.

81. Morton JM, Brown A, Galanko JA, Norton JA, Grimm IS, Behrns KE. A national comparison of surgical versus percutaneous drainage of pancreatic pseudocysts: 1997-2001. Journal of gastrointestinal surgery : official journal of the Society for Surgery of the Alimentary Tract. 2005;9(1):15-20; discussion -1.

82. Akshintala VS, Saxena P, Zaheer A, Rana U, Hutfless SM, Lennon AM, et al. A comparative evaluation of outcomes of endoscopic versus percutaneous drainage for symptomatic pancreatic pseudocysts. Gastrointestinal endoscopy. 2014;79(6):921-8; quiz 83.e2, 83.e5.

83. Keane MG, Sze SF, Cieplik N, Murray S, Johnson GJ, Webster GJ, et al. Endoscopic versus percutaneous drainage of symptomatic pancreatic fluid collections: a 14-year experience from a tertiary hepatobiliary centre. Surgical endoscopy. 2016;30(9):3730-40.

84. Park DH, Lee SS, Moon SH, Choi SY, Jung SW, Seo DW, et al. Endoscopic ultrasound-guided versus conventional transmural drainage for pancreatic pseudocysts: a prospective randomized trial. Endoscopy. 2009;41(10):842-8.

85. Varadarajulu S, Christein JD, Tamhane A, Drelichman ER, Wilcox $\mathrm{CM}$. Prospective randomized trial comparing EUS and EGD for transmural drainage of pancreatic pseudocysts (with videos). Gastrointestinal endoscopy. 2008;68(6):1102-11.

86. Varadarajulu S, Bang JY, Sutton BS, Trevino JM, Christein JD, Wilcox CM. Equal efficacy of endoscopic and surgical cystogastrostomy for pancreatic pseudocyst drainage in a randomized trial. Gastroenterology. 2013;145(3):583-90.e1.

87. Varadarajulu S, Lopes TL, Wilcox CM, Drelichman ER, Kilgore ML, Christein JD. EUS versus surgical cyst-gastrostomy for management of pancreatic pseudocysts. Gastrointestinal endoscopy. 2008; 68(4):649-55.

88. Melman L, Azar R, Beddow K, Brunt LM, Halpin VJ, Eagon JC, et al. Primary and overall success rates for clinical outcomes after laparoscopic, endoscopic, and open pancreatic cystgastrostomy for pancreatic pseudocysts. Surgical endoscopy. 2009;23(2):267-71. 